\title{
Physiological Effects of Leptin, Insulin and Triamcinolon on Adult Male Japanese Quail
}

\author{
M. MÁČAJOVÁ ${ }^{1}$, D. LAMOŠOVÁ ${ }^{1}$, M. ZEMAN ${ }^{1,2}$
}

${ }^{1}$ Institute of Animal Biochemistry and Genetics, Slovak Academy of Sciences, Ivanka pri Dunaji, Slovakia ${ }^{2}$ Department of Animal Physiology and Ethology, Comenius University, Bratislava, Slovakia

Received June 17, 2003

Accepted September 22, 2003

\begin{abstract}
Máčajová M., D. Lamošová, M. Zeman: Physiological Effects of Leptin, Insulin and Triamcinolon on Adult Male Japanese Quail. Acta Vet. Brno 2003, 72: 515-522.

The effects of leptin, insulin and triamcinolone on body weight, food intake and some physiological parameters of adult Japanese quail males were investigated in this study. Hormones were administered intramuscularly for 4 days. The birds were weighed and decapitated 24 hours after the last dose. Drug administration did not change the body weight of quail. The weight of testes decreased and the weight of liver increased $(P<0.001)$ after administration of triamcinolone. Food intake in animals treated with leptin and insulin did not change, but after triamcinolone administration higher food consumption $(P<0.01)$ was recorded. The activity of alkaline phosphatase in plasma was significantly higher in triamcinolone $(P<0.001)$ treated group compared to control. After triamcinolone administration the amount of proteins in muscle decreased $(P<0.05)$. Concentration of leptin in plasma among groups did not differ. The most considerable changes were observed after triamcinolone injection, especially in glucose and lipid metabolism.

Food intake, glucose, protein, lipid, triacylglycerol, alkaline phosphatase
\end{abstract}

Leptin, hormone produced mainly by adipocytes, plays an important role as a signal of the body fat content to the brain, where it regulates food intake and energy expenditure (Friedman and Halaas 1998). Weight loss results in decreased leptin levels, while the weight gain significantly increases circulating leptin concentrations. Leptin is not only important in the regulation of food intake and energy balance, but it appears increasingly as a general metabolic hormone involved in many physiological processes including inhibition of insulin secretion from $\beta$-cells of the pancreas (Fehmann et al. 1997), stimulation of glucose utilization (Kamohara et al. 1997), stimulation of lipolysis in adipocytes (Frühbeck et al. 1997) and increasing of fatty acids synthesis in liver (Cohen et al. 1998). Leptin has been detected in several species, including non-mammalian vertebrates, like chicken (Taouis et al. 1998), fish (Johnson et al. 2000), frogs, lizards and snakes (Muruzábal et al. 2002).

Insulin is one of the main metabolic hormones and is significantly involved in the regulation of energy processes. Insulin enhances glucose disposal, storage and oxidation in muscles. It controls the metabolites required in the muscle and is involved in maintaining glucose homeostasis. Generally, insulin is considered to be an anabolic hormone. Avian metabolism is notable for a high blood glucose level and a weak hypoglycemic effect of heterologous insulin. Plasma levels of insulin vary considerably in birds, and concentrations are consistently much higher than its levels found in mammals (Hazelwood 1986). A possible interaction between leptin and insulin was suggested by the strong correlations between fasting serum leptin and insulin levels in humans (Widjaja et al. 1997). Insulin stimulates leptin secretion (Patel et al. 1998), on the other side, administration of leptin reduces plasma insulin levels (Harris 1998).

Address for correspondence:

Mgr. Mariana Máčajová

Institute of Animal Biochemistry and Genetics

Slovak Academy of Sciences
Moyzesova 61,900 28 Ivanka pri Dunaji, Slovak republic
Phone: +4210245943232

Fax. +4210245943932

E-mail: mariana.macajova@ savba.sk 
Triamcinolone is a commonly used synthetic glucocorticoid. Glucocorticoids have a huge number of effects on physiological systems including stimulation of gluconeogenesis (particularly in the liver), inhibition of glucose uptake in muscle and adipose tissue and stimulation of fat breakdown in adipose tissue. Glucocorticoids modulate food intake and body weight and are potent regulators of leptin expression. Dexamethasone has been shown to stimulate leptin production in vitro (Murakami et al. 1995). In fasted mice, with reduced leptin levels, amount of corticosterone in plasma was increased (Ahima et al. 1998).

The purpose of this study was to determine the effect of recombinant murine leptin, porcine insulin and triamcinolone, injected intramusculary for four days, on body weight, food intake and some metabolic parameters in adult Japanese quail males.

\section{Materials and Methods}

Adult males (eight weeks old) of Japanese quail (Coturnix Japonica, laying line) from our breeding colony were divided into four groups with average body weight $114.3 \pm 2.0 \mathrm{~g}$. Quail were kept in individual cages. The birds from control group $(\mathrm{C}, \mathrm{n}=7$ ) were intramuscularly (breast muscle) injected with $50 \mu 1$ of phosphate buffered saline (PBS). L-group $(n=6)$ was injected with $10 \mu \mathrm{g}$ of murine leptin (Pepro Tech, EC, England) dissolved in $50 \mu \mathrm{l}$ of PBS, I-group $(\mathrm{n}=6)$ with $20 \mu \mathrm{g}$ of porcine insulin (Biomedicals, Inc., USA) dissolved in $50 \mu \mathrm{l}$ of PBS and T-group $(\mathrm{n}=7$ ) with $10 \mu \mathrm{g}$ of triamcinolone (Serva, Germany) dissolved in $50 \mu \mathrm{l}$ of olive oil during four days. The possible influence of olive oil was tested in a pilot experiment, where intramuscular administration of olive oil had no physiological effects. Feeding mash (HYD-01, $210 \mathrm{~g}$ of nitrogenous substances per kilogram of feed, $12 \mathrm{MJ} / \mathrm{kg}$ of metabolizable energy) and water were provided ad libitum. The lighting was continuous during the whole experimental period. 24 hours after the last dose quail were weighed, decapitated and blood was collected into heparinized tubes and 10 minutes centrifugated $(2500 \mathrm{~g}$, $4{ }^{\circ} \mathrm{C}$ ). Plasma was stored at $-20{ }^{\circ} \mathrm{C}$ until assayed for hormone leptin and metabolic parameters. The internal organs were weighed and the part of liver and breast muscle were taken for determination of metabolic parameters. $100 \mathrm{mg}$ of each tissue was homogenized in $1 \mathrm{ml}$ of redistilled water. Concentration of leptin in plasma was measured by mouse leptin radioimmunoassay kit (Linco Research, Inc., USA). A $\gamma$-counter JNG 402 (URVJT, Slovakia) was used for the measurement of radioactivity. Concentration of glucose, cholesterol, triacylglycerols, total lipids and activity of alkaline phosphatase in plasma, and in liver and breast muscle homogenate were analyzed by commercially available kits Bio-la-test (Lachema, Czech republic). Protein content was quantified with bovine serum albumin as a standard (Lowry et al. 1951). Data are presented as means \pm S.E.M. The results were analyzed by one-way analysis of variance (ANOVA) using SigmaPlot and STATISTICA software. Groups with significant differences were compared with posthoc Tukey test.

\section{Results}

The body weight of Japanese quail did not change after treatment with leptin, insulin and triamcinolone (Fig. 1A). No statistically significant changes were observed in spleen and testes weight, but triamcinolone significantly $(P<0.001)$ increased weight of the liver (Fig. 1B, C, D). Administration of leptin and insulin did not affect food intake in birds, but triamcinolone significantly $(P<0.01)$ increased this parameter (Fig. 2A). The activity of alkaline phosphatase in plasma was higher in triamcinolone $(P<0.001)$ group compared to control (Fig.2B). No changes in concentration of leptin in plasma between groups were recorded. Application of leptin and insulin did not influence the amount of cholesterol in plasma, but triamcinolone significantly $(P<0.001)$ increased its level (Fig.2D).

Treatment with triamcinolone significantly $(P<0.001)$ rised lipids in plasma, liver and breast muscle (Fig. 3A, B, C). Injection of triamcinolone significantly increased also triacylglycerols (TAG) in plasma, liver and muscle (Fig. 3D, E, F), while the application of leptin and insulin did not significantly change the amounts of lipids and TAG in plasma, liver and muscle.

The amounts of proteins in plasma, liver and muscle were not affected by administered drugs, with exception of lower level of proteins $(P<0.05)$ in muscle after triamcinolone 

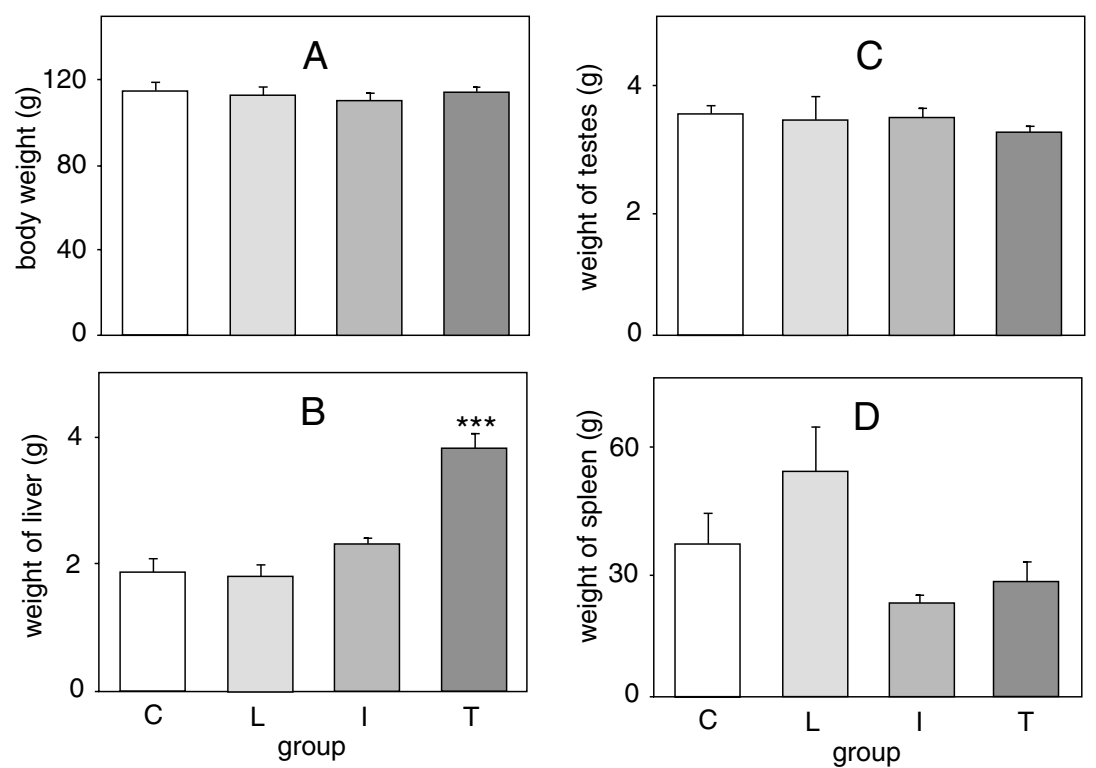

Fig. 1. Body weight (A), weights of liver (B), testes (C) and spleen (D) of adult Japanese quail males after leptin, insulin and triamcinolone intramuscular administration $(n=5-7)$. White columns designate the control group (C) treated with PBS, grey columns group treated with leptin (L), dark grey columns group treated with insulin (I) and black columns group treated with triamcinolone $(\mathrm{T})$. Values represent means \pm S.E.M, $* * * P<0.001$ vs control.
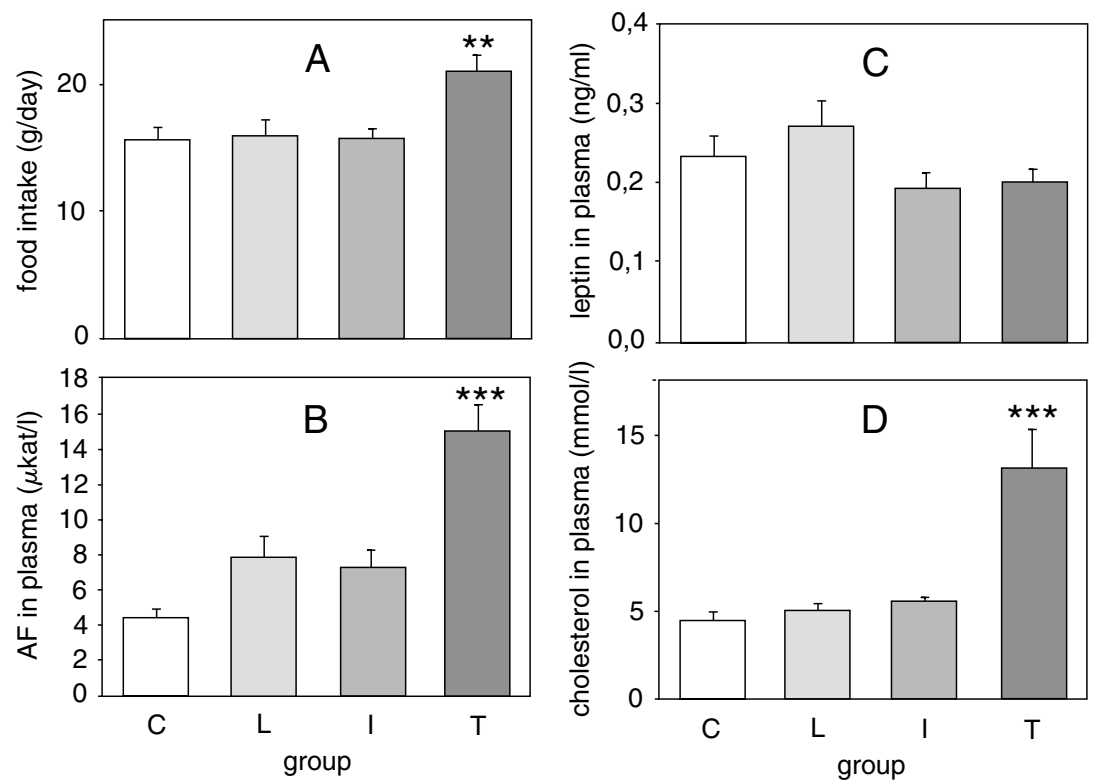

Fig. 2. Food intake (A), activity of alkaline phosphatase (AF) in plasma (B) concentration of leptin (C) and cholesterol (D) in plasma of adult Japanese quail males after leptin, insulin and triamcinolone intramuscular administration $(\mathrm{n}=5-7)$. For legend see Fig. 1. Values represent means \pm S.E.M, $* * P<0.01, * * * P<0.001$ vs control. 

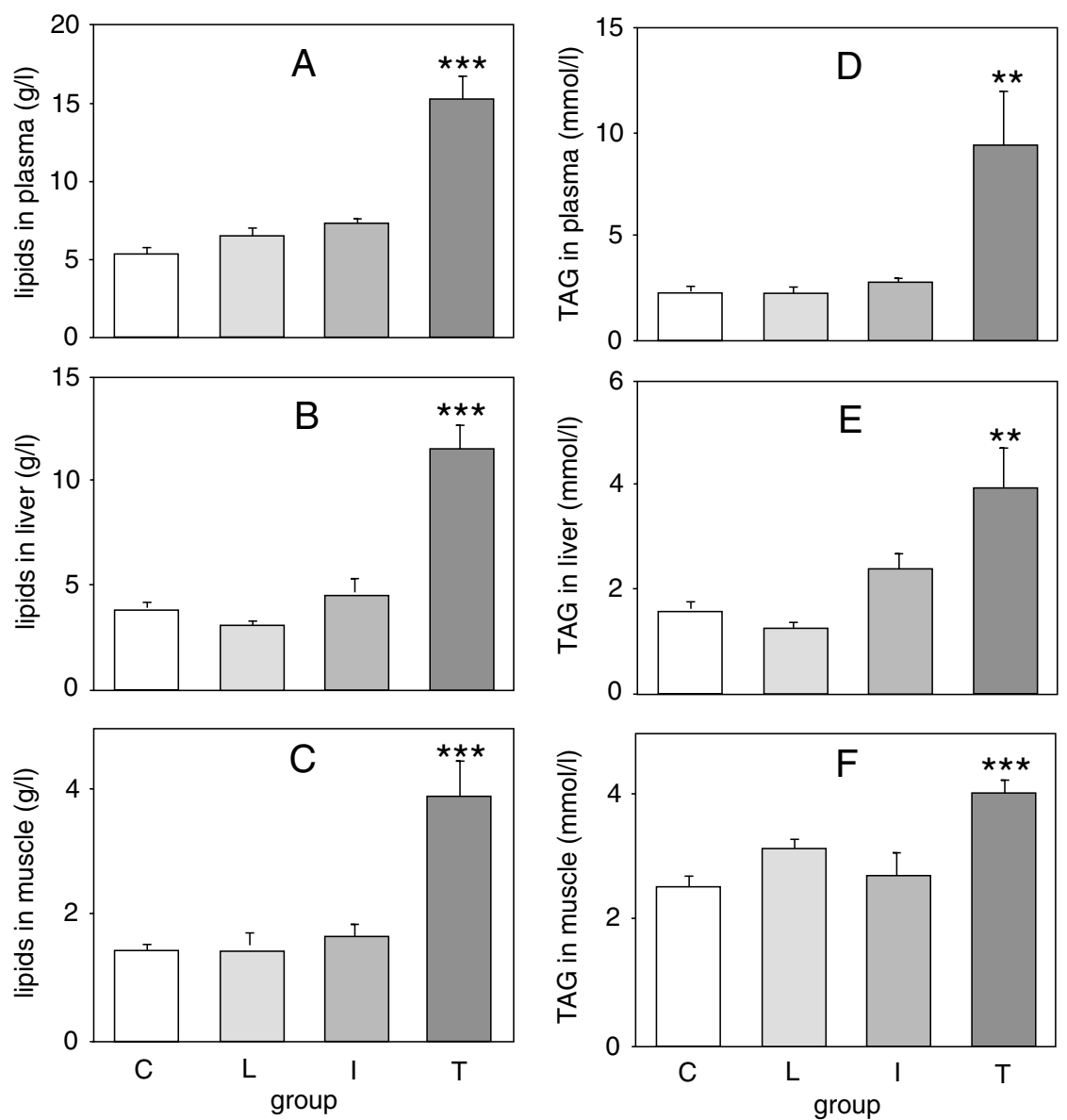

Fig. 3. Concentrations of total lipids in plasma (A), in the liver (B), in the breast muscle (C), concentrations of triacylglycerols (TAG) in plasma (D), in the liver $(\mathrm{E})$ and in the breast muscle $(\mathrm{F})$ of adult Japanese quail males after leptin, insulin and triamcinolone intramuscular administration $(n=6-7)$. For legend see Fig.1. Values represent means \pm S.E.M, $* * P<0.01, * * * P<0.001$ vs control.

administration (Fig. 4A, B, C). The higher concentration of glucose $(P<0.01)$ was noticed in plasma in the group treated with triamcinolone (Fig. 3D). Triamcinolone injection also significantly increased the amounts of glucose in the liver and breast muscle $(P<0.001$; Fig. 4E, F).

\section{Discussion}

Leptin gene homologues have been cloned in several species. Taou is et al. (1998) have cloned chicken leptin, with $97 \%$ similarity to the mouse sequences. But the leptin homology among avian and mammalian species is still a subject of discussion (Friedman-Einat et al. 1999). Because of the supposed close similarity in the primary structures of the mammalian and avian leptin, and because it has been found that chick embryonic cells are sensitive to mouse leptin (Lamošová and Zeman 2001), we used commercially available recombinant murine leptin and mouse leptin RIA kit for determination of leptin in plasma in our experiments. 

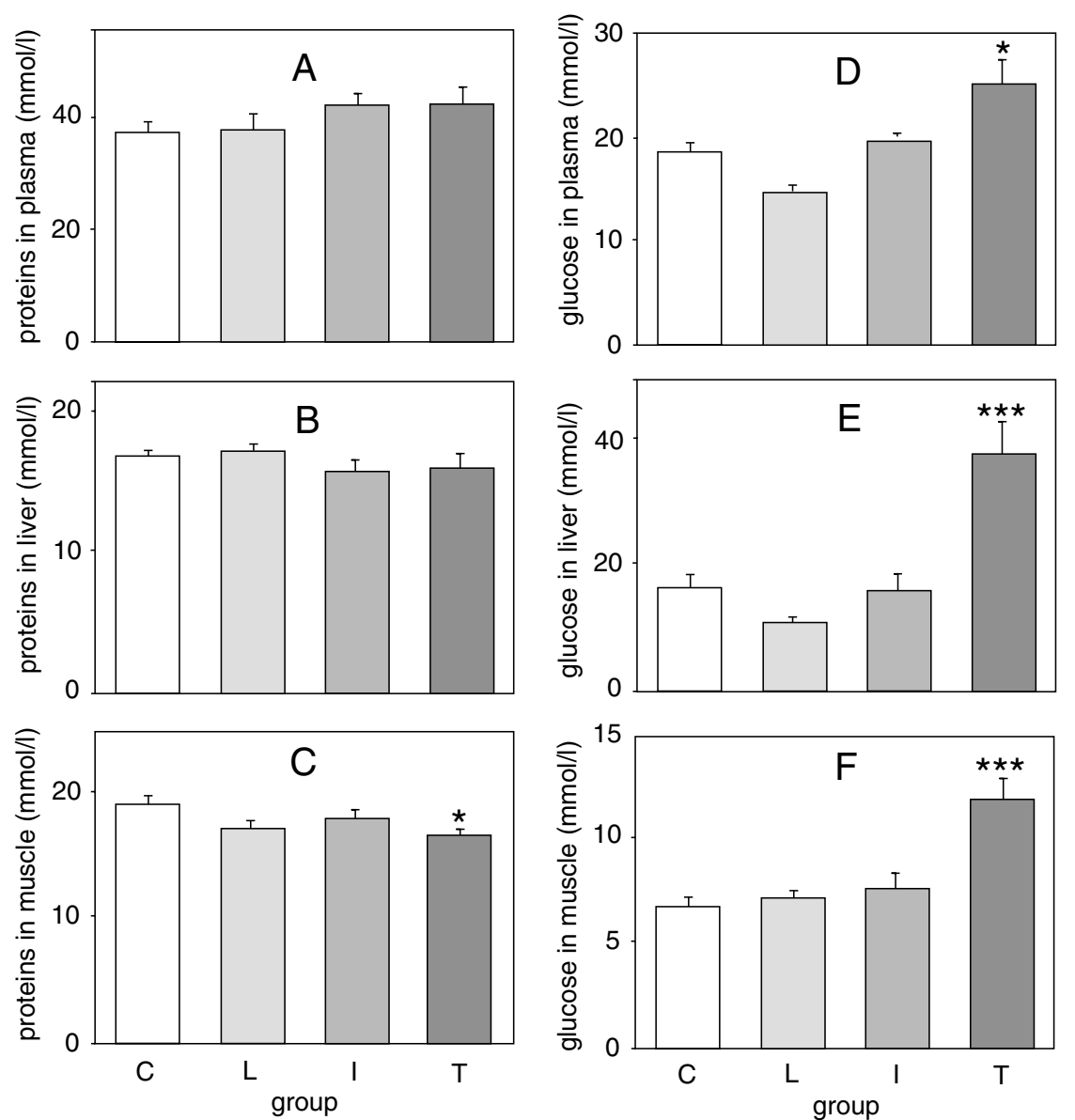

Fig. 4. Concentrations of total proteins in plasma (A), in the liver (B), in the breast muscle (C), concentrations of glucose in plasma (D), in the liver (E) and in the breast muscle (F) of adult Japanese quail males after leptin, insulin and triamcinolone intramuscular administration $(n=6-7)$. For legend see Fig.1. Values represent means \pm S.E.M, $* P<0.05$, *** $P<0.001$ vs control.

Treatment of chickens with porcine insulin for four days significantly increased leptin expression in the liver but not in adipose tissue (Ashwell et al. 1999). A sub-chronic treatment of chickens with dexamethasone (a synthetic glucocorticoid) also increases leptin expression in the liver. As with insulin treatment, dexamethasone did not affect leptin levels in adipose tissue (Ashwell et al. 1999). Thus, the action of insulin and dexamethasone on leptin expression seems to be tissue specific. We did not notice changes in concentration of leptin in plasma after administration of leptin, insulin and triamcinolone in our experiment. Plasma leptin levels in adult Japanese quail males measured in our study were approximately ten times lower than in adult cocks (Gallus domesticus) observed by Dridi et al. (2000). Leptin concentrations in chickens are regulated by the nutritional state with higher levels in the fed state and lower in the fasted state. Concentrations of this hormone depend upon the age, with higher leptin levels found in 22-week-old layer hens as compared to 15-week-old. There are not published data on plasma leptin concentrations in Japanese quail till now. Moreover, the heterologous radioimmunoassay we used in our study does not allow us to 
speculate about possible interspecific differences in plasma leptin levels between the chickens and Japanese quail.

The body weight of Japanese quail in our experiment did not change after treatment with leptin, insulin and triamcinolone. It is known, that glucocorticoids act directly upon gonads to render them resistant to stimulation by sex hormones (estrogen or testosterone). Glucocorticoids used for a long time can inhibit the secretion of sex hormones from the pituitary gland, causing hypogonadism that can result in infertility. Intramuscular administration of prednisole (synthetic glucocorticoid) to rats for twelve days caused decrease of absolute gonadal and adrenal weights (Se well et al. 1982). Administration of triamcinolone in our study decreased the weight of testes, but not significantly.

Intramuscular administration of murine recombinant leptin and insulin in our study did not affect food intake in Japanese quail, although an inhibitory effect of leptin and the mutated analog (Cys3) on food intake was observed in young chickens (Dridi et al. 2000). In older layer genotype chickens, a single intraperitoneal injection of ovine or chicken leptin exerted a significant reduction in food intake (from 11 to 34\%) in animals being refed after 2 hours of fasting. The effect lasted more than 5 hours but disappeared after 10 hours (Dridi et al. 2000). Murine leptin injected directly into the chicken central nervous system caused no alteration in food intake (B ungo et al. 1999). On the other hand, another study clearly showed that intracerebroventricular administration of human leptin decreased food intake in two chicken genotypes (broiler and layer) at a dose of $10 \mu \mathrm{g}$, which is in good agreement with results obtained in mammals (Denbow et al. 2000). The contradictory results from all these studies may be attributed also to the source of leptin or to the age of animals used, or to the technique of administration. Whereas insulin injections increase food intake in mammals, similar injection have no effect in birds (S a vory 1987). The feed consumption in our experiment was significantly higher in quail treated with triamcinolone. The effect of glucocorticoids on food intake in birds vary with the physiological state and species. In studies on doves (Koch et al. 2002), daily intracerebroventricular injections of dexamethasone increased food intake by $25-50 \%$ in both sexes, and further studies in males revealed that the increase was directly related to the dose. Exogenous corticosterone and other glucocorticoids increase food intake in birds, gastrointestinal transit time and fat deposition, largerly in the abdomen (Tur et al. 1989). This increase in abdominal fat is supported by slight peripheral lipolysis and enhanced lipogenesis by an enlarged liver (Buyse et al. 1987). Furthermore, it has been demonstrated that chronic treatment of chickens with corticosterone induces insulin resistance and hyperinsulinemia with increased adiposity and fat deposit in the liver (Ta ou is et al. 1993). Also in our study administration of triamcinolone results in a significant increase in the liver weight and in the amount of total lipids and TAG in liver, plasma and muscle.

Alkaline phosphatase is a dephosphorylating enzyme that is active in many tissues including the bone, liver, kidney, intestine, lung and placenta. It is known, that circulating leptin levels are positively corelated with total alkaline phosphatase activity in both men and women (Iwamoto et al. 2000; Martini et al. 2001). Exposure to exogenous glucocorticoids can also increase the serum alkaline phosphatase activity in rats ( $\mathrm{Nadra}$ et al. 2003) and dogs (Ginel et al. 2002). Our results are in agreement with above mentioned findings in mammals. The activity of alkaline phosphatase in Japanese quail plasma was significantly higher after triamcinolone administration and showed growing trend in insulin and leptin groups.

Intramuscular injection of triamcinolone in our study caused a significant reduction of protein concentrations in breast muscle. Dietary glucocorticoids induced a decrease in growth and body weight in cockerels (Hay a shi et al. 1994) that is largely due to an increase in net muscle protein catabolism. 
Insulin is a powerful hypoglycemic agent in mammals but birds usually require administration of considerably larger amounts of the hormone to achieve the same degree of hypoglycemia. Administration of insulin to Japanese quail in this experiment did not affect the amount of glucose in plasma, liver and muscle. On the other side, we noticed significantly higher concentration of glucose in triamcinolone group. We suppose that glucose motilization in our experiment results from the enhanced expression of enzymes involved in gluconeogenesis, which is probably the best known metabolic function of glucocorticoids in animals. Similarly, exogenous corticosterone in the chicken increased plasma glucose concentrations (Thurston et al. 1993).

Chronic administration of leptin has been shown to cause a reduction in plasma glucose and insulin levels in diabetic obese mice (Halaas et al. 1997). Several studies have shown that leptin increases insulin sensitivity in normal animals. The acute infusion of leptin increased glucose turnover and skeletal muscle glucose uptake in lean C57BL/6J mice (Kamohara et al. 1997). Four days administration of leptin in our study decreased glucose levels in plasma (but not significant), suggesting that leptin may influence glucose uptake and turnover in target tissues also in birds.

Presented data enlarge knowledge about a role of main metabolic hormones in intermediate metabolism in Japanese quail, the important model species of gallinaceous birds.

\section{Vplyv leptínu, inzulínu a triamcinolonu na vybrané fyziologické parametre dospelých samcov prepelice japonskej}

V našej práci sme sledovali účinky leptínu, inzulínu a triamcinolonu na telesnú hmotnost', príjem krmiva a niektoré fyziologické ukazovatele u dospelých samcov prepelice japonskej. Hormóny sme aplikovali intramuskulárne počas štyroch dní. 24 hodín po poslednej aplikácii sme zvieratá vážili a dekapitovali. V telesnej hmotnosti prepelíc sme nezaznamenali žiadne zmeny. U zvierat, ktorým bol podávaný triamcinolon, sa signifikantne zvýšila hmotnost' pečene $(P<0,01)$. Podávanie leptínu a inzulínu neovplyvnilo príjem krmiva, ale po aplikácii triamcinolonu sme zaznamenali vyššiu spotrebu krmiva $(P<0,01)$. Aktivita alkalickej fosfatázy $\mathrm{v}$ plazme bola $\mathrm{v}$ porovnaní $\mathrm{s}$ kontrolou signifikantne vyššia po podaní triamcinolonu $(P<0,001)$. Po aplikácii triamcinolonu sa znížilo aj množstvo bielkovín $\mathrm{v}$ prsnom svale $(P<0,05)$. V koncentrácii leptínu $\mathrm{v}$ plazme sme medzi skupinami nezaznamenali signifikantné rozdiely. Najvýraznejšie zmeny sme pozorovali po podaní triamcinolonu, zvlášt v metabolizme glukózy a tukov.

\section{Acknowledgements}

This work was supported by grants from the Slovak Grant Agency for Science VEGA (No.2/1015/01;2/8208/01) and Science and Technology Assistance Agency (APVT/20/016502).

\section{References}

AHIMA, RS, PRABAKARAN, D, FLIER, JS 1998: Postnatal leptin surge and regulation of circadian rhytm of leptin by feeding: implications for energy homeostasis and neuroendocrine function. J Clin Invest 101: 1020-1027

ASHWELL, CHM, CZERWINSKI, SM, BROCHT, DM, McMURTRY, JP 1999: Hormonal regulation of leptin expression in broiler chickens. Am J Phys 276: 226-232

BUNGO, T, SHIMOJO, M, MASUDA, Y, TACHIBANAB, T, TANAKA, S, SUGAHARA, K, FURUSE, M 1999: Intraventricular administration of mouse leptin does not reduce food intake in the chicken. Brain Res 817: 196-198

BUYSE, J, DECUYPERE, E, SHARP, PJ, HUZBRECHTS, LM, KÙHN, ER, WHITEHEAD, C 1987: Effect of corticosterone on circulating concentrations of corticosterone, prolactin, thyroid hormones and somatomedin $\mathrm{C}$ and fattening in broilers selected for high or low fat content. J Endocrinol 112: 229-237

COHEN, SM, WERRMAN, J, TOTA, M 1998: ${ }^{13} \mathrm{C}$ NMR study of the effects of leptin treatment on kinetics of hepatic intermediary metabolism. Proc Natl Acad Sci USA 95: 7385-7390 
DENBOW, DM, MEADE, S, ROBERTSON, A, McMURTRY, JP, RICHARDS, M, ASHWELL, CH 2000: Leptin-induced decrease in food intake in chickens. Physiol Behav 69: 359-362

DRIDI, S, RAVER, N, GUSSAKOVSKI, EE, DEROUET, M, PICARD, M, GERTLER, A, TAOUIS, M 2000 Biological activities of recombinant chicken leptin C4S analog compared with unmodified leptins. Am J Physiol 279: $116-123$

FEHMANN, HC, PEISER, C, BODE, HP 1997: Leptin: A potent inhibitor of insulin secretion. Peptides 18: 1267-1273

FRIEDMAN, JM, HALAAS, JL 1998: Leptin and the regulation of body weight in mammals. Nature 395: 763-770

FRIEDMAN-EINAT, M, BOSWELL, T, HOREV, G, SHARP, P 1999: The chicken leptin gene: has it been cloned? Gen Comp Endocrinol 115: 354-363

FRÚHBECK, G, AGUADO, M, MARTINEZ, JA 1997: In vitro lipolytic effect of leptin on mouse adipocytes: Evidence for a possible autocrine/paracrine role of leptin. Biochem Biophys Res Commun 240: 590-594

GINEL, PJ, LUCENA, R, FERNÁNDEZ, M 2002: Duration of increased serum alkaline phosphatase activity in dogs receiving different glucocorticoid doses. Res Vet Sci 72: 201-204

HALAAS, JL, BOOZER, C, BLAIR-WEST, J, FIDAHUSEIN, N, DENTON, DA, FRIEDMAN, JM 1997 Physiological response to long-term peripheral and central leptin infusion in lean and obese mice. Proc Natl Acad Sci USA 94: 8878-8883

HARRIS, RB 1998: Acute and chronic effects of leptin on glucose utilization in lean mice. Biochem Biophys Res Commun 245: 502-509

HAYASHI, K, NAGAY, Y, OHTSUKA, A, TOMITA, Y 1994: Effects of dietary corticosterone and trilostane on growth and skeletal muscle protein turnover in broiler cockerels. Br Poult Sci 35: 789-798

HAZELWOOD, RL 1986: Carbohydrate metabolism. In: STURKIE, PD (Ed): Avian physiology. Springer-Verlag, New York, pp. 303-325

IWAMOTO, I, DOUCHI, T, KOSHA, S, MURAKAMI, M, FUJINO, T, NAGATA, Y 2000: Relationships between serum leptin level and regional bone mineral density, bone metabolic markers in healthy women., Acta Obstet Gyn Scan 79: 1060-1064

JOHNSON, RM, JOHNSON, TM, LONDRAVILLE, RL 2000: Evidence for leptin expression in fishes. J Exp Zool 286: $718-724$

KAMOHARA, S, BURCELIN, R, HALAAS, JL 1997: Acute stimulation of glucose metabolism in mice by leptin treatment. Nature 389: $374-377$

KOCH, KA, WINGFIELD, JC, BUNTIN, JD 2002: Glucocorticoids and parental hyperphagia in ring doves (Streptopelia risoria). Horm Behav 41: 9-21

LAMOŠOVÁ, D, ZEMAN, M 2001: Effect of leptin and insulin on chick embryonic muscle cells and hepatocytes. Physiol Res 50: 183-189

LOWRY, OH, ROSEBROUGH, NJ, FARR, AL, RANDALL, RJ 1951: Protein measurement with Folin phenol reagent. J Biol Chem 193: 265-275

MARTINI, G, VALENTI, R, GIOVANI, S, CAMPAGNA, S, FRANCI, B, NUTI, R 2001: Leptin and body composition in healthy postmenopausal women. Panminerva Med 22: 415-420

MURAKAMI, T, IIDA, M, SHIMA, K 1995: Dexamethasone regulates obese expression in isolated rat adipocytes. Biochem Biophys Res Commun 214: 1260-1267

MURUZÁBAL, FJ, FRÙHBECK, G, GÓMEZ-AMBROSI, J, ARCHANCO, M, BURREL, MA 2002: Immunocytochemical detection of leptin in non-mammalian vertebrate stomach. Gen Comp Endocrinol 128: 149-152

NADRA, R, MENUELLE, P, CHEVALLIER, S, BERDAL, A 2003: Regulation by glucocorticoids of cell differentiation and insulin-like growth factor binding protein production in cultured fetal rat nasal chondrocytes. J Cell Biochem 88: 911-922

PATEL, B, KOENIG, J, KAPLAN, L, HOOI, S 1998: Increase in plasma leptin and Lep mRNA concentrations by food intake is dependent on isulin. Metabolism 47: 603-607

SAVORY, CJ 1987: How closely do circulating blood glucose levels reflect feeding state in fowls? Comp Biochem Physiol 88: 101-106

SEWELL, RG, GALLUS, JA, NANRY, KP 1982: Prednisolone effects upon body and organ weights, water intake, and several behaviors. Pharm Biochem Behav 17: 1225-1231

TAOUIS, M, CHEN, JW, DAVIAUD, C, UPONT, J, DEROUET, M, SIMON, J 1998: Cloning the chicken leptin gene. Gene 208: 239-242

TAOUIS, M, DEROUET, M, CHEVALIER, B, SIMON, J 1993: Corticosterone effect on insulin receptor number and kinase activity in chicken muscle and liver. Gen Comp Endocrinol 89: 167-175

THURSTON, RJ, BRYANT, CC, KORN, N 1993: The effects of corticosterone and catecholamine infusion on plasma glucose levels in chicken (Gallus domesticus) and turkey (Meleagris gallopavo). Comp Biochem Physiol 106: 59-62

TUR, J, ESTEBAN, S, RAYO, JM, MORENO, M, MIRALLES, A, TUR, JA 1989: Effect of glucocorticoids on gastrointestinal emptying in young broilers. Br Poult Sci 30: 693-698

WIDJAJA, A, STRATTON, IM, HORN, R, HOLMAN, RR, TURNER, R, BRABANT, G 1997: Plasma leptin, obesity, and plasma insulin in type 2 diabetic subjects. J Clin Endocrinol Metab 82: 654-657 